\title{
Beavers promote calicioid diversity in boreal forest landscapes
}

\section{Vehkaoja, Mia}

2017-03

Vehkaoja , M , Nummi , P \& Rikkinen , J 2017 , ' Beavers promote calicioid diversity in boreal forest landscapes ' , Biodiversity and Conservation , vol. 26 , no. 3 , pp. 579-591 . https://doi.org/10.1007/s105

http://hdl.handle.net/10138/308586

https://doi.org/10.1007/s10531-016-1259-7

acceptedVersion

Downloaded from Helda, University of Helsinki institutional repository.

This is an electronic reprint of the original article.

This reprint may differ from the original in pagination and typographic detail.

Please cite the original version. 


\section{Beavers promote calicioid diversity in boreal forest landscapes}

\section{Mia Vehkaoja, Petri Nummi \& Jouko Rikkinen}

Biodiversity and Conservation

ISSN 0960-3115

Biodivers Conserv

DOI 10.1007/s10531-016-1259-7

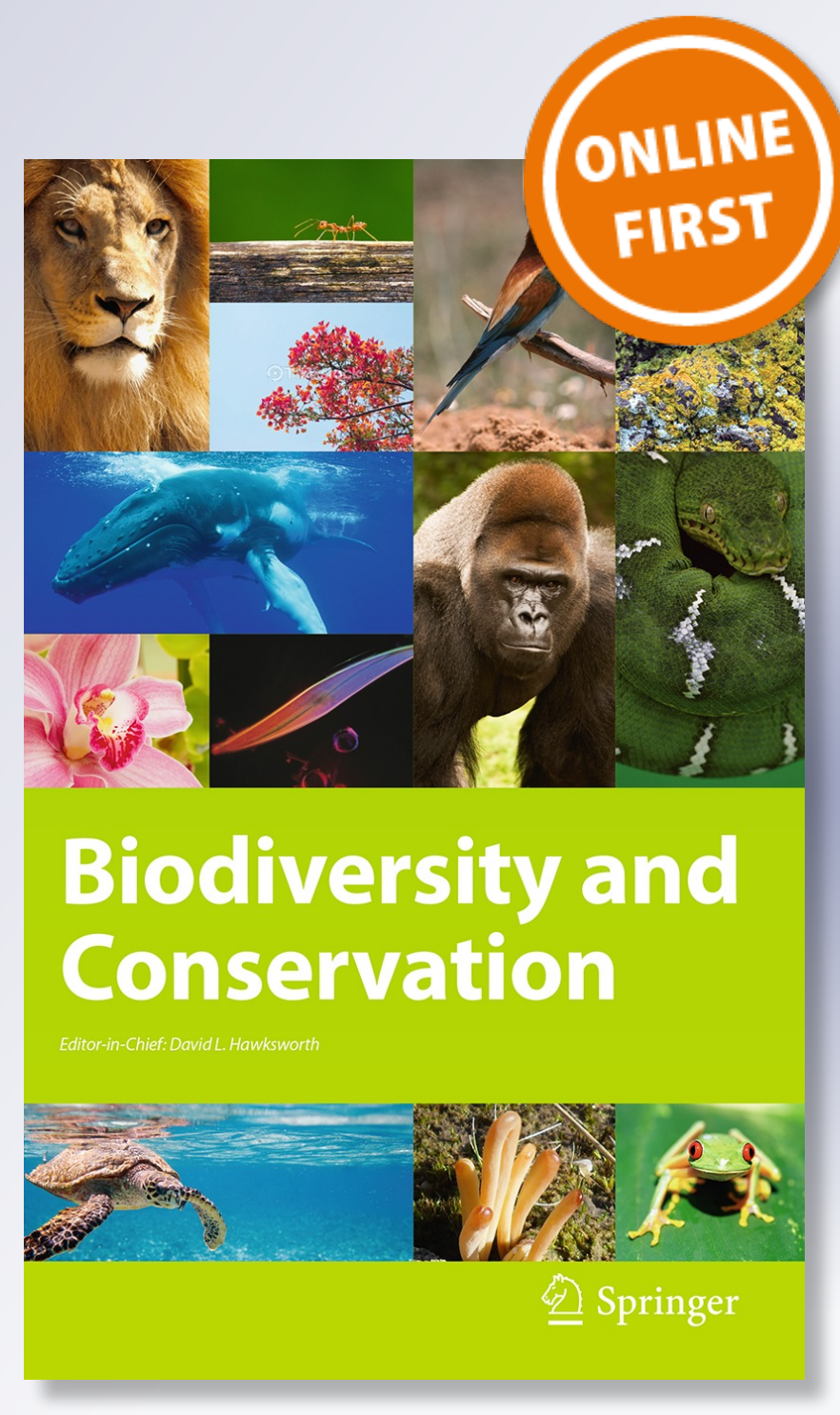

黛 Springer 
Your article is protected by copyright and all rights are held exclusively by Springer Science +Business Media Dordrecht. This e-offprint is for personal use only and shall not be selfarchived in electronic repositories. If you wish to self-archive your article, please use the accepted manuscript version for posting on your own website. You may further deposit the accepted manuscript version in any repository, provided it is only made publicly available 12 months after official publication or later and provided acknowledgement is given to the original source of publication and a link is inserted to the published article on Springer's website. The link must be accompanied by the following text: "The final publication is available at link.springer.com". 


\title{
Beavers promote calicioid diversity in boreal forest landscapes
}

\author{
Mia Vehkaoja ${ }^{1} \cdot$ Petri Nummi $^{1} \cdot$ Jouko Rikkinen $^{2}$
}

Received: 16 March 2016/Revised: 4 November 2016/Accepted: 16 November 2016

(C) Springer Science+Business Media Dordrecht 2016

\begin{abstract}
Beavers are ecosystem engineers that modify and maintain a range of special habitat types in boreal forests. They also produce large quantities of deadwood that provide substrate for many lignicolous organisms such as calicioid fungi (Ascomycota). We studied how calicioid diversity differed between boreal riparian forests with and without beaver activity. The results show that calicioid diversity were significantly higher at beaver sites compared to the other two forest site types studied. The large quantity and diverse forms of deadwood produced by beavers clearly promotes calicioid diversity in the boreal landscape. The specific lighting and humidity conditions within beaver wetlands could be the reason why they promote the success of certain calicioid species.
\end{abstract}

Keywords Deadwood · Flood · Pin lichen · Riparian forest $\cdot$ Snag

\section{Introduction}

Ecosystem engineers are animals that modify the environment of other organisms while fulfilling their own needs. The physical processes they perform often include digging, burrowing, and damming (Gutiérrez and Jones 2006; Wright and Jones 2006). These

Communicated by David Hawksworth.

This article belongs to the Topical Collection: Forest and plantation biodiversity.

Electronic supplementary material The online version of this article (doi:10.1007/s10531-016-1259-7) contains supplementary material, which is available to authorized users.

\section{Mia Vehkaoja}

mia.vehkaoja@helsinki.fi

1 Department of Forest Sciences, University of Helsinki, P.O.Box 27, 00014 Helsinki, Finland

2 Department of Biosciences, University of Helsinki, P.O.Box 65, 00014 Helsinki, Finland 
actions tend to increase environmental heterogeneity and thus enhance the biota. The use of ecosystem engineers in conservation biology and ecosystem restoration is a relatively new approach for promoting biodiversity (Byers et al. 2006; Bartel et al. 2010).

Beavers are important ecosystem engineers in many Northern Hemisphere forest ecosystems, and can promote biodiversity in several ways (Jones et al. 1994; Nummi and Holopainen 2014). These effects arise mainly from damming streams and lakes, and maintaining these flooded habitats (Baker and Hill 2003). Flooding drastically changes abiotic and biotic conditions, and creates favorable habitats for many organisms from invertebrates to fish and frogs to birds (Collen and Gibson 2001; Rosell et al. 2005), whereas these changes hinder other species groups such as trees and other terrestrial vegetation. Many ecosystem engineers have been observed to alleviate the physical stress of certain organisms in severe environments (Crain and Bertness 2006), such as in the harsh boreal climate, where the ecological role of beaver activity may be especially important. The induced disturbances generate free space and new niches that are essential for weak competitors, including many lignum-dependent insects, bryophytes, and fungi (Rikkinen 2003a; Flecker and Taylor 2004; Caruso et al. 2008; Lõhmus and Lõhmus 2011).

Bryophytes and lichens are an important part of the biological diversity in boreal forests, with many species having specialized to growing on deadwood (e.g. Laaka 1995; Johansson 1997; Kuusinen and Siitonen 1998; Stokland et al. 2012). Calicioids, often also referred to as pin lichens, are a polyphyletic but ecologically distinct group of lichens and associated fungi (Tibell 1984, 1999; Hawksworth et al. 1995; Rikkinen 1995, 2003b; Selva 2003; Spribille and Björk 2008). They produce tiny $(<4 \mathrm{~mm})$, usually well-stalked apothecia (fruit bodies). Many calicioids are lignicolous and commonly occur on snags (standing deadwood). Many are also highly substrate-specific and require a specific type of forest environment. They have consequently been used as biomonitors of forest ecosystem health, particularly ecological continuity (Tibell 1992; Holien 1998; Selva 2003, 2014; Lõhmus and Lõhmus 2011).

By flooding shoreline forests and injuring living trees beavers cause tree mortality and other disturbances (Rosell et al. 2005; Nummi and Kuuluvainen 2013). Locally these actions may significantly increase the amount of standing deadwood and coarse woody debris (CWD, $\geq 10 \mathrm{~cm}$ in diameter) (Thompson et al. 2016), which are limiting resources for numerous boreal forest species (Hahn and Christensen 2005; Stokland et al. 2012). Intensive forestry in Fennoscandia has changed many forests into even-aged stands with very little deadwood (Esseen et al. 1997; Östlund et al. 1997; Gamfeldt et al. 2013). On the landscape-level the amount of CWD has decreased by over 90\% (Siitonen 2001). The general reduction in deadwood volumes has been accompanied by significant reductions in the diversity of different deadwood types (Ekbom et al. 2006; Rudolphi et al. 2011). Snags, deciduous deadwood, and well-decayed deadwood have disappeared from managed forests (Sippola et al. 1998; Rudolphi et al. 2011), and all these changes have induced population declines e.g. in nearly 2000 forest-dependent species in Sweden (Gärdenfors 2005).

Several studies have reported the positive effects beavers bear on various wetlandassociated species groups, including bats (Nummi et al. 2011), frogs (Vehkaoja and Nummi 2015), and aquatic invertebrates (McDowell and Naiman 1986), and demonstrated that sometimes entire species groups benefit from beaver activities (Nummi and Holopainen 2014). Beavers produce large amounts of deadwood, including several rare deadwood types (Thompson et al. 2016). From this background arises the interesting and relevant question of how beaver-induced flooding affects deadwood-associated 
biodiversity, particularly calicioids that require deadwood and prefer microhabitats with relatively high atmospheric humidity.

To our best knowledge, our study is the first to specifically investigate the diversity of organisms on beaver-generated deadwood. We hypothesize that calicioid richness differ between beaver-occupied riparian forests and non-beaver riparian forests. Secondly, we assume that the species composition of calicioid communities in boreal forest landscapes with beaver wetlands differs from those without. Our study has been conducted in conjunction with Thompson et al. (2016), and the pin lichen samples have been gathered from the same sites and concurrently as the deadwood surveys conducted in that study.

\section{Materials and methods}

\section{Study sites}

Our study was conducted at two study areas: Evo $\left(61^{\circ} 10^{\prime} \mathrm{N}, 25^{\circ} 05^{\prime} \mathrm{E}\right)$ with a strong beaver population and Nuuksio $\left(60^{\circ} 19^{\prime} \mathrm{N}, 2^{\circ} 28^{\prime} \mathrm{E}\right)$ with no beaver habitation. Both sites are located in southern Finland and represent relatively large and well-preserved forest landscapes (Evo $66.5 \mathrm{~km}^{2}$ and Nuuksio $53 \mathrm{~km}^{2}$ ). They include over $100 \mathrm{small}$, humic headwater lakes with an average surface area of $0.043 \mathrm{~km}^{2}$, connected with brooks and thus forming a complex network within the forest landscape (see Järvinen et al. 2002; Arvola et al. 2010).

The beavers at Evo are American beavers (Castor canadensis) and most local beaver lakes have been formed by damming existing lakes (Nummi and Hahtola 2008). Beavers choose their home lake according to a suitable outlet and the presence of suitable forage. The resident beavers occupy one site for an average of three years, and tend to recolonize abandoned patches after a ca. 10-year absence (Hyvönen and Nummi 2008). The original native Eurasian beaver (Castor fiber) was hunted to extinction in Finland in 1868, but may have disappeared from the southern parts of the country by the end of the 1500s (Linnamies 1956; Lahti and Helminen 1974). Both European and American beavers were reintroduced to Finland in the mid-1930s, before it was realized that they represent two different species (Parker et al. 2012). They currently occur in different parts of Finland, but neither species has yet re-/colonized the Nuuksio region.

Both study areas support boreal coniferous forests with scattered patches of deciduous forest. Intensive forestry has influenced forest structure at both sites until the 1980s/1990s. Forest management has for example enhanced the dominance of Scots pine (Pinus sylvestris). Nuuksio was designated a national park in 1994, and forest management apart from small-scale restoration schemes has ceased since then. Evo continues to be managed, but management practices are fairly light in areas that are not used for silvicultural teaching. Several small conservation areas have also been established within the area.

A total of 18 riparian forest sites were analyzed in our study, 12 from Evo and six from Nuuksio. All our study sites represent lakeside forests, and are the same as in Thompson et al. (2016). Lakes in the Evo area have been monitored for beavers since 1976, giving a clear indication of which local lakes are suitable for the species. In addition, we have yearspecific information on the impoundment history of each site (when the flood was created, how long it lasted and how far it reached, and when the lakes were reoccupied). From the aerial photographs we can identify the time period when the tree stand died/lost its bark. Six study sites were randomly chosen from all sites with recorded beaver activity during 
2010-2014. Recently occupied habitats were targeted because we wished to study sites where flooding effects were still clearly evident, and to compare these with sites displaying no signs of beaver activity. The six randomly chosen non-inhabited sites from Evo were used as patch controls. These sites were located in the same drainage basins as the beaver sites, but had remained uninhabited either because of their unsuitable shore vegetation, lack of an inlet or outlet suitable for damming, and/or other reasons (Vehkaoja et al. 2015). The non-beaver sites in Nuuksio were used as landscape controls. While they were located in a different drainage basin, they otherwise closely resembled the Evo beaver sites and would have represented ideal habitat for beavers in both resource availability and inlet/ outlet occurrence, if only the species were present in the region. The landscape controls were used to compare landscape-level differences of calicioid diversity. The selection criteria for all study sites were lake size, characteristics of shoreline vegetation, and the presence of an aboveground inlet or outlet suitable for beaver damming. After categorizing all potential Nuuksio sites based on these criteria, six sites were randomly chosen for our study. The forests within the three different site groups were very similar in characteristics, displaying no significant differences in measured forest structure variables (e.g. species composition, proportion of coniferous vs. deciduous trees, canopy height, and diameter at breast height) (online Appendix). Forest structure variables were calculated using relascope measurements (Bitterlich 1947, 1948).

\section{Sampling}

Primary edge influences produced by beavers (e.g. tree mortality) extend at least tens of meters from the shoreline into the forest (Harper et al. 2005). We defined the width of the riparian zone as $40 \mathrm{~m}$, so as to ensure the inclusion of the entire primary edge (Komonen et al. 2008). We established two equal-sized rectangular sampling plots at each site, running $10 \mathrm{~m}$ along the shore and $40 \mathrm{~m}$ perpendicular from the shoreline, with a total area of 0.04 ha per plot. At sites where flooding was still present, we waded out as far into the flooded area as possible, to reach the original shoreline of the lake. The first sampling plot was situated on the widest flood meadow section of the riparian zone and the other plot directly across from it on the opposite side of the lake. No differences were observed in the average deadwood amounts between the two sampling plots of the sites (online Appendix). We randomly selected ten standing dead trees (with a diameter of $5 \mathrm{~cm}$ or more and at least $80 \mathrm{~cm}$ high) from each sampling plot, and recorded all calicioid species present from the base to a height of $200 \mathrm{~cm}$. If less than ten standing dead trees were present at a site, we sampled living trees instead. The field inventories were carried out during the summer of 2014 at the same sites, sampling plots, and time as the deadwood surveys in Thompson et al. (2016).

\section{Species identification}

All selected tree trunks were carefully searched to locate all calicioid lichens and fungi present. Specimens were collected for later analysis whenever calicioid fungi were encountered. The specimens were identified in the laboratory by examining their anatomical details under dissecting and compound microscopes, and checking for speciesspecific color reactions to $\mathrm{KOH}$ solution from squash mounts of ascomata in water (Tibell 1999; Tuovila 2013). The nomenclature follows Tibell (1999). 


\section{Statistical analyses}

Calicioid species richness was calculated for each site $(n=18)$ and each tree $(n=360)$ by comparing the data between the site types, trees and whether the trees were standing in water or on land. Species richness is a count data variable with a Poisson distribution (loglink function). The study site type effect (Evo beaver, Evo non-beaver and Nuuksio) on species richness was analyzed using generalized linear modeling with the glm function and the tree-scale species richness and in-water/on-land species richness were analyzed using a generalized linear mixed model (Bolker et al. 2009; Zuur et al. 2009) fit by maximum likelihood with the glmer function in the lme4 library (Bates and Maechler 2009) in R 3.0.2 ( $\mathrm{R}$ Development Core team 2013). The tree-scale data are zero-inflated, but to retain simplicity we used the data as it was. However, this must be kept in mind when interpreting the results. Site type explained the calicioid species richness observed in the 18 study sites. Site type also explained the calicioid species richness of the 360 trees. Site type was used as a categorical parameter. Standing in water and on land were also used as categorical parameters. A random part (Site) was included in the tree-scale models.

Spearman's rank correlation coefficient was used to determine whether calicioid species richness correlated with the amount of total deadwood, snags, deciduous deadwood, and trunk diameter of the studied trees (for deadwood measurements, see Thompson et al. 2016).

We calculated the Jaccard index of similarity to examine the similarity of pin lichen communities between site types (Evo beaver, Evo non-beaver and Nuuksio). Jaccard's index of similarity is

$$
S_{\mathrm{J}}=\mathrm{c} /(\mathrm{a}+\mathrm{b}+\mathrm{c}),
$$

where $\mathrm{a}$ is the number of unique species in habitat $\mathrm{A}, \mathrm{b}$ is the number of unique species in habitat $\mathrm{B}$, and $\mathrm{c}$ is the number of species shared by both habitats. The Jaccard index compares samples based on the presence or absence of species. We selected this similarity index to emphasize species composition and because it does not dilute the importance of rare species. We combined the two sampling plots from within each site to arrive at a composite community for that given site. We then estimated the dissimilarity between the sites as $1-S_{\mathrm{J}}$. In a broad sense, dissimilarity can be considered turnover (Koleff et al. 2003), and it produces an estimate of the sum of the species unique to either habitat divided by the regional pool (Gaston et al. 2001).

$$
1-S_{\mathrm{J}}=(\mathrm{a}+\mathrm{b}) /(\mathrm{a}+\mathrm{b}+\mathrm{c})
$$

(Sabo and Soykan 2014).

To estimate the proportion of unique species in each site type (Evo beaver, Evo nonbeaver and Nuuksio), we used the formula created by Sabo and Soykan (2014)

$$
\alpha \mathrm{X}, \mathrm{u}=\mathrm{a} /(\mathrm{a}+\mathrm{b}+\mathrm{c}) .
$$

We additionally estimated the proportional increase in the regional species pool due to $\mathrm{X}$ site types as

$$
\gamma \mathrm{X}=\mathrm{a} /(\mathrm{b}+\mathrm{c})
$$




\section{Results}

A total of 23 calicioid species representing six different genera were recorded from the study sites (online Appendix). Twenty species were found from beaver sites, whereas 13 and six species were observed from the patch control (Evo non-beaver) and landscape control (Nuuksio) sites, respectively. The highest calicioid diversity (13 species) was recorded from Kärppijärvi (beaver site), while three Nuuksio sites had no calicioids (Table 1). Approximately $26 \%$ of calicioid species were recorded from only one site and no single species was recorded from all the study sites (online Appendix). We found calicioids on 96 of the 360 studied trees, and therefore only $26.7 \%$ of the sampled trees had calicioids. Only seven deadwood specimens sampled at the beaver sites were standing on dry land, while the rest were standing in water. All the calicioid species found solely from beaver sites grew on snags standing in water (Table 2).

The most commonly encountered calicioid species were Chaenotheca ferruginea (11 sites/35 trees), Mycocalicium subtile (9 sites/30 trees), and Calicium glaucellum (6 sites/13 trees). Beaver sites had eight calicioid species that did not occur on other site types, while three species from the total 23 were not found from a single beaver site (online Appendix). Calicioid species richness was significantly higher in the shoreline forests of beaver sites than in the other two site types (Table 3). However, tree-scale species richness did not differ between Evo beaver and Evo non-beaver sites. On the other hand, tree-scale species richness was significantly higher at the Evo beaver sites compared to the Nuuksio sites

Table 1 Species richness of the study sites

\begin{tabular}{|c|c|c|c|c|c|c|}
\hline Site & Site type & $\begin{array}{l}\text { Number of } \\
\text { pin lichen } \\
\text { species }\end{array}$ & $\begin{array}{l}\text { Number of } \\
\text { snags } \\
\text { sampled }\end{array}$ & $\begin{array}{l}\text { Number of } \\
\text { live trees } \\
\text { sampled }\end{array}$ & $\begin{array}{l}\text { Number of } \\
\text { deciduous } \\
\text { trees sampled }\end{array}$ & $\begin{array}{l}\text { Amount of } \\
\text { deadwood } \\
\mathrm{m}^{3} / \mathrm{ha} \text { (snag) }\end{array}$ \\
\hline Huhmari 1 & Evo beaver & 8 & $20[16]$ & 0 & $12[9]$ & $35.60(28.52)$ \\
\hline Huhmari 2 & Evo beaver & 5 & 20 [7] & 0 & 9 [3] & $45.08(42.37)$ \\
\hline Kärppijärvi & Evo beaver & 13 & $20[8]$ & 0 & $11[1]$ & $32.90(25.36)$ \\
\hline Löytjärvi & Evo beaver & 2 & $20[2]$ & 0 & 0 & $19.29(8.54)$ \\
\hline Saarijärven oja & Evo beaver & 6 & $20[7]$ & 0 & 0 & $276.9(125.77)$ \\
\hline Vähä-Keltajärvi & Evo beaver & 10 & $20[14]$ & 0 & $4[3]$ & $20.71(7.36)$ \\
\hline Mustarimpi & Evo non-beaver & 6 & $8[5]$ & $12[3]$ & $2[2]$ & $13.65(1.85)$ \\
\hline Pitkänniemenjärvi & Evo non-beaver & 3 & $6[0]$ & $14[6]$ & $1[0]$ & $20.25(1.56)$ \\
\hline Rahtijärvi & Evo non-beaver & 2 & $20[2]$ & 0 & $1[0]$ & $13.11(6.56)$ \\
\hline Ruuttanajärvi & Evo non-beaver & 4 & $10[1]$ & $10[2]$ & $1[1]$ & $20.73(9.10)$ \\
\hline Valkjärvi & Evo non-beaver & 4 & 0 & $20[6]$ & $1[0]$ & $22.38(0)$ \\
\hline Ylinen Mustajärvi & Evo non-beaver & 5 & $8[4]$ & $12[6]$ & 0 & $10.76(1.76)$ \\
\hline Haukjärvi & Nuuksio & 4 & $5[4]$ & $15[0]$ & $2[0]$ & $14.64(4.74)$ \\
\hline Majalampi & Nuuksio & 2 & $3[0]$ & $17[1]$ & $3[0]$ & $5.32(0.03)$ \\
\hline Mustalampi & Nuuksio & 0 & 2 & 18 & 5 & $11.41(2.30)$ \\
\hline Myllyjärvi & Nuuksio & 0 & 5 & 15 & 10 & $1.58(0.94)$ \\
\hline Mylly-Majalampi & Nuuksio & 0 & 0 & 20 & 6 & $9.99(0)$ \\
\hline Väärä Musta & Nuuksio & 2 & $2[1]$ & $18[4]$ & $1[0]$ & $4.79(0.36)$ \\
\hline
\end{tabular}

Numbers in brackets indicate the number of trees with calicioids present for each given tree type (snag, live tree and deciduous) 
Table 2 Characteristics of substrates from which pin lichen species were found

\begin{tabular}{|c|c|c|c|c|c|c|}
\hline & Coniferous & Deciduous & Corticated & Decorticated & In water & On land \\
\hline \multicolumn{7}{|l|}{ Only from beaver sites } \\
\hline Calicium abietinum & & 1 & & 1 & 1 & \\
\hline Chaenotheca brachypoda & 2 & & & 2 & 2 & \\
\hline Chaenotheca chrysocephala & 2 & & & 2 & 2 & \\
\hline Chaenotheca gracillima & 3 & & & 3 & 3 & \\
\hline Chaenotheca trichialis & 4 & & & 4 & 4 & \\
\hline Chaenothecopsis savonica & 4 & 2 & & 6 & 6 & \\
\hline Microcalicium disseminatum & 2 & & & 2 & 2 & \\
\hline Species A & 1 & & & 1 & 1 & \\
\hline \multicolumn{7}{|l|}{ Only from non-beaver sites } \\
\hline Calicium denigratum & 1 & & & 1 & & 1 \\
\hline Chaenothecopsis pusiola & 4 & & & 4 & & 4 \\
\hline Cyphelium inquinans & 1 & & 1 & & & 1 \\
\hline
\end{tabular}

Table shows species found solely from either beaver or non-beaver sites. The deadwood characteristics are coniferous or deciduous, corticated or decorticated, and whether the deadwood was standing in water or on land. Species A represents potentially an undescribed species

Table 3 Differences between Evo beaver, Evo non-beaver, and Nuuksio sites in terms of pin lichen species richness

\begin{tabular}{|c|c|c|c|c|}
\hline & Estimate & SE & z-value & p-value \\
\hline \multicolumn{5}{|l|}{ Site-scale richness } \\
\hline Evo beaver sites (intercept) & 1.992 & 0.151 & 13.216 & 0.000 \\
\hline Evo non-beaver sites ${ }^{a}$ & -0.606 & 0.254 & -2.389 & 0.017 \\
\hline Nuuksio sites $^{\mathrm{a}}$ & -1.705 & 0.384 & -4.435 & $<0.001$ \\
\hline \multicolumn{5}{|l|}{ Tree-scale richness } \\
\hline Evo beaver sites (intercept) & -0.571 & 0.303 & -1.884 & 0.059 \\
\hline Evo non-beaver sites & -0.457 & 0.433 & -1.054 & 0.292 \\
\hline Nuuksio sites ${ }^{\mathrm{a}}$ & -1.864 & 0.507 & -3.672 & $<0.001$ \\
\hline \multicolumn{5}{|l|}{ Tree-scale richness } \\
\hline Trees standing on land (intercept) & -1.463 & 0.271 & -5.394 & 0.000 \\
\hline Trees standing in water & 0.492 & 0.401 & 1.228 & 0.219 \\
\hline
\end{tabular}

Estimate represents the lake type coefficient, SE denotes standard error, z-value the test value, and p-value the statistical significance. The value of the intercept is compared to values of the other sites/categories. If this value is negative, it is subtracted from the intercept value and if it is positive, it is added to the intercept value

a Statistically significant

(Table 3). Additionally, the regional species pool of the beaver sites was more versatile than that of the other two site types (Table 4). As a landscape feature it should be noted that the two Evo site types resembled each other more than they resembled the Nuuksio sites. All species recorded from beaver sites were collected from deadwood. Both the total 
Table 4 Species pool similarities between study site types

\begin{tabular}{llllll}
\hline & $S_{\mathrm{J}}$ & $1-S_{\mathrm{J}}$ & $\alpha \mathrm{A}$ & $\alpha \mathrm{B}$ & $\gamma$ \\
\hline Beaver sites (A) - Evo non beaver sites(B) & 0.476 & 0.524 & 0.381 & 0.143 & 0.615 \\
Beaver sites (A) - Nuuksio sites (B) & 0.300 & 0.700 & 0.700 & 0.000 & 2.333 \\
Evo non beaver sites (A) - Nuuksio sites (B) & 0.267 & 0.733 & 0.600 & 0.133 & 1.500 \\
\hline
\end{tabular}

$S_{\mathrm{J}}$ is Jaccard's index of similarity, which express how similar the species pools of two habitat types are to each other. $1-S_{\mathrm{J}}$ is the Jaccard distance, which measures the dissimilarity in a species pool between two habitat types. $\alpha \mathrm{A}$ is the proportion of unique species in habitat $\mathrm{A}$ and $\alpha \mathrm{B}$ is the proportion of unique species in habitat B. $\gamma$ is the proportional increase in the regional species pool due to habitat $\mathrm{A}$

Table 5 Correlation between species richness

\begin{tabular}{lrr}
\hline & $r_{\mathrm{s}}$ & $\mathrm{p}$ \\
\hline Species richness & & 0.758 \\
Amount of deadwood $^{\mathrm{a}}$ & 0.294 & 0.000 \\
Amount of deciduous deadwood $^{\text {Diameter of deadwood }}$ & -0.373 & 0.236 \\
Amount of snags $^{\mathrm{a}}$ & 0.599 & 0.127 \\
\hline
\end{tabular}

Association of species richness with the amount of deadwood, snags, deciduous deadwood, and diameter $(\mathrm{n}=18)$. Spearman's rank correlation coefficient $\left(r_{\mathrm{s}}\right)$ was used for all correlation analyses. $\mathrm{p}$ - statistical significance

a Statistically significant

amount of deadwood and the number of snags (Table 1) positively correlated with calicioid species richness, whereas the amount of deciduous deadwood or deadwood diameter did not (Table 5).

While the ascomata of one mycocalicioid taxon (Chaenothecopsis sp. A) resembled those of Chaenothecopsis nana and Mycocalicium subtile, it could also potentially represent an undescribed species. Many undescribed members of this diverse and poorly studied group (Mycocaliciales) are estimated to exist even in the comparatively wellknown boreal forests of Northern Europe (Tuovila 2013).

\section{Discussion}

Our results show that beaver activity can enhance calicioid species richness. The high species richness we observed around beaver ponds is obviously mainly explained by the large amounts and diverse forms of deadwood produced by beaver activity. The species richness of calicioid lichens and fungi positively correlated both with the overall amount of deadwood and with the number of snags at the forest sites. Ecosystem engineers often increase species richness especially at initially low-productivity sites (Wright and Jones 2004), and this also appears to be true in our boreal setting. Beaver activity produces a range of different deadwood substrates (Thompson et al. 2016), which can then be colonized by a wide range of calicioid species.

Wright et al. (2002) found that species richness between beaver and non-beaver sites did not differ, but on the other hand species richness was significantly higher in beaver 
landscapes compared to non-beaver landscapes. Our study shows a similar phenomenon, but at a smaller scale. Tree-scale species richness did not differ between Evo's beaver and non-beaver sites, while site-scale richness did. Moreover, Evo as a beaver landscape had higher species richness when compared to the landscape without beavers (Nuuksio). Therefore the beaver effect was evident in our study both at the site and landscape scales, but not at the tree scale.

Wetlands in the boreal landscape generally experience few disturbances (Liu and Hytteborn 1991; Kuuluvainen 1994). However, beaver activity produces a whole continuum of disturbances in such areas (Nummi and Kuuluvainen 2013). Moreover, these disturbances tend to create new relatively competitor-free living spaces for calicioids and other small organisms that have adopted to growing on hard standing lignum. Many calicioids are known to be substrate-specific and only occur on vertical deadwood surfaces (Rikkinen 1995, 2003a, b; Holien 1998; Kuusinen and Siitonen 1998; Lõhmus and Lõhmus 2011), which, in turn, represent a suboptimal substrate for lignicolous bryophytes and macrolichens. The latter rapidly colonize stumps and fallen logs and can effectively outcompete calicioids and crustose lichens from such substrates (Prestø 1994; Caruso et al. 2008).

Many species of calicioid lichens and fungi benefit from high atmospheric humidity and are vulnerable to abrupt changes in forest microclimate (Holien 1996; Lõhmus and Lõhmus 2011). The close relationship between calicioids and old-growth forest structures is well established (Tibell 1992; Selva 1994, 2013, 2014; Holien 1996; Kuusinen and Siitonen 1998). Old-growth forest features of boreal forests enhance calicioid diversity in several ways. Aged forests provide a variety of suitable substrates and microenvironments that combine favorable lighting conditions with high atmospheric humidity. Most calicioid species suffer from major disturbances such as extensive forest fires. However, they appear to benefit from a legacy of small- and medium-scale disturbances such as those caused by local storms, slope and shoreline processes, insect outbreaks, and as in this case, beaver activity. On the whole, differences in disturbance histories may often explain a significant proportion of present-day variations in calicioid diversity (Rikkinen 1995, 2003b).

Nearly all calicioid lichens and fungi recorded from the beaver sites were found growing on snags standing in water. Such snags are typically exposed to direct sunlight but can also provide fungi with a more or less constant supply of water through capillary conduction. Atmospheric humidity also remains constantly high and light reflection from the water and/or ice and snow may also benefit the lichenized species. Many boreal calicioid lichens are believed to be cheimophotophytic, i.e. they are often found from microhabitats that are exposed to highest light levels during late winter and/or early spring (Rikkinen 1995, 2003b). Thus, in addition to the wide range of suitable substrates produced by beaver activity (cf. Rikkinen 2003a), the favorable lighting and humidity regime is also likely to contribute to the high diversity of calicioid lichens and fungi around beaver ponds.

Old, unmanaged boreal forests typically have a high quantity and wide diversity of different deadwood substrate types (Kuusinen and Siitonen 1998; Lassauce et al. 2011). Such forests have unfortunately been affected and often severely degraded by human activities, resulting not only in degraded but also highly fragmented forest landscapes. Human activities have led to a major decline of old-growth forests in Europe and to the subsequent regional extinctions of old-growth-associated species, including many lignicolous species (Berg et al. 1994; Samuelsson et al. 1994). Many calicioid lichens and fungi are also currently more or less restricted to old-growth forests.

Beaver sites clearly represent important retention patches for a plethora of old-growthassociated organisms at Evo, where forestry has molded the forest landscape for centuries. 
Beaver activity maintains a diverse matrix of retention patches, and provides a constant supply of new substrates for saproxylic organisms. It also simultaneously generates new suitable habitats for many non-saproxylic species including mayflies, fish, frogs, waterfowl, and bats (Nummi 1989; Schlosser and Kallemeyn 2000; Nummi and Hahtola 2008; Nummi et al. 2011; Vehkaoja and Nummi 2015). These biodiversity hot spots wander in the landscape as beavers move in search of new resources (Vehkaoja et al. 2015).

\section{Conclusions}

Our current findings support the idea that beavers, as ecosystem engineers, can aid the conservation of many rare and/or threatened species and species groups. Pin lichens are considered good bio-indicators of forest ecological continuity and health (e.g. Selva 2003). Therefore our new results show a link between the deadwood dynamics created by beavers and pin lichen richness, and how the riparian forests of beaver sites can further the ecological continuity of boreal forests at both the site and landscape scales.

Previously beavers have been shown to facilitate species groups that depend on aquatic environments at least during some part of their life (e.g. frogs, waterfowl). Our findings show that beavers also promote species groups that occur on land. By conserving beavers we can concurrently conserve species with varying habitat requirements. The conservation of ecosystem engineers has been described as an all-inclusive and cost-effective tool for ecosystem conservation (Bangert and Slobodchikoff 2006; Byers et al. 2006; Crain and Bertness 2006). And, as even the International Union for Conservation of Nature (IUCN) is moving from single-species conservation towards larger scales, a clear interest can be seen in focusing conservation aims towards whole ecosystems and landscapes exhibiting high biodiversity (Franklin 1993; Hanski 1999; Turner et al. 2003). Beavers, as ecosystem engineers, play a key role in maintaining ecosystem functions and retaining biodiversity, and therefore ecosystem engineer conservation should be given more emphasis in conservation biology.

Acknowledgements Funding was kindly provided by the Maj and Tor Nessling Foundation. Special thanks to Stella Thompson for grammatical corrections. Anonymous referees are thanked for their comments on the manuscript.

Funding MV was funded by the Maj and Tor Nessling Foundation during the study (20150065; 201400098; 201300039). The foundation did not have a role in the formulation of the study design, or in the collection, analyses, or interpretation of the data. They additionally did not influence the writing of the report, or the decision to submit our paper for publication.

\section{Compliance with ethical standards}

Conflict of interest The authors declare that they have no conflict of interest.

\section{References}

Arvola L, Rask M, Ruuhijärvi J, Tulonen T, Vuorenmaa J, Ruoho-Airola T, Tulonen J (2010) Long-term patterns in $\mathrm{pH}$ and colour in small acidic boreal lakes of varying hydrological and landscape settings. Biogeochemistry 101:269-279 
Baker BW, Hill EP (2003) Beaver (Castor canadensis). In: Feldhamer GA, Thompson BC, Chapman JA (eds) Wild mammals of North America: biology, management, and conservation, 2nd edn. The Johns Hopkins University Press, Baltimore, pp 288-310

Bangert RK, Slobodchikoff CN (2006) Conservation of prairie dog ecosystem engineering may support arthropod beta and gamma diversity. J Arid Environ 67:100-115

Bartel RA, Haddad NM, Wright JP (2010) Ecosystem engineers maintain a rare species of butterfly and increase plant diversity. Oikos 119:883-890

Bates D, Maechler M (2009) lme4: linear mixed-effects models using S4 classes (Computer software manual). http://CRAN.R-project.org/package=lme4

Berg A, Ehnström B, Gustavsson L, Hallingbäck T, Jonsell M, Weslien J (1994) Threatened plant, animal, and fungus species in Swedish forests: distribution and habitat associations. Conserv Biol $8(3): 718-731$

Bitterlich W (1947) Die Winkelzählmessung. Allg Forst-und Holzwirtsch Ztg 58:94-96

Bitterlich W (1948) Die Winkelzählprobe. Allgemeine Forst- und Holzwirtschaftliche Zeitung 59:4-5

Bolker BM, Brooks ME, Clark CJ, Geange SW, Poulsen JR, Stevens MHS, White J-SS (2009) Generalized linear mixed models: a practical guide for ecology and evolution. Trends Ecol Evol 24(3):127-135

Byers JB, Cuddington K, Jones CG, Talley TS, Hastings A, Lambrinos JG, Crooks JA, Wilson WG (2006) Using ecosystem engineers to restore ecological systems. Trends Ecol Evol 21(9):493-500

Caruso A, Rudolphi J, Thor G (2008) Lichen species diversity and substrate amounts in young planted boreal forests: a comparison between slash and stumps of Picea abies. Biol Conserv 141:47-55

Collen P, Gibson RJ (2001) The general ecology of beavers (Castor spp.), as related to their influence on stream ecosystems and riparian habitats, and the subsequent effects on fish-a review. Rev Fish Biol Fish 10:439-461

Crain CM, Bertness MD (2006) Ecosystem engineering across environmental gradients: implications for conservation and management. Bioscience 56:211-218

Ekbom B, Schroeder LM, Larsson S (2006) Stand specific occurrence of coarse woody debris in a managed boreal forest landscape in central Sweden. For Ecol Manag 221:2-12. doi:10.1016/j.foreco.2005.10. 038

Esseen PA, Ehnström B, Ericson L, Sjöberg K (1997) Boreal forests. Ecol Bull 46:16-47

Flecker AS, Taylor BW (2004) Tropical fishes as biological bulldozers: density effects on resource heterogeneity and species diversity. Ecology 85:2267-2278

Franklin JF (1993) Preserving biodiversity: species, ecosystems, or landscapes? Ecol Appl 3:202-205

Gamfeldt L et al (2013) Higher levels of multiple ecosystem services are found in forests with more tree species. Nat Commun 4:1340. doi:10.1038/ncomms 2328

Gärdenfors U (2005) The 2005 red list of Swedish species. Swedish University of Agricultural Sciences, Uppsala

Gaston KJ, Rodrigues ASL, van Rensburg BJ, Koleff P, S1 Chown (2001) Complementary representation and zones of ecological transition. Ecol Lett 4:4-9

Gutiérrez JL, Jones CG (2006) Physical ecosystem engineers as agents of biogeochemical heterogeneity. Bioscience 56:227-236

Hahn K, Christensen M (2005) Dead wood in European forest reserves-a reference for forest management. In: Marchetti M (ed) Monitoring and indicators of forest biodiversity in Europe-from ideas to operationality, vol 51. European Forest Institute Proceedings, Florence, pp 181-191

Hanski I (1999) Metapopulation ecology. Oxford University Press, New York

Harper KA, MacDonald SE, Burton PJ, Chen J, Brosofske KD, Saunders SC, Euskirchen ES, Roberts D, Jaiteh MS, Esseen P-A (2005) Edge influence on forest structure and composition in fragmented landscapes. Conserv Biol 19(3):768-782

Hawksworth DL, Kirk PM, Sutton BC, Pegler DM (1995) Ainsworth \& Bisby's dictionary of the fungi, 8th edn. CAB International, Wallingford

Holien H (1996) Influence of site and stand factors on the distribution of crustose lichens of the caliciales in a suboceanic spruce forest area in central Norway. Lichenologist 28(4):315-330

Holien H (1998) Lichens in spruce forest stands of different successional stages in central Norway with emphasis on diversity and old growth species. Nova Hedwig 66:283-324

Hyvönen T, Nummi P (2008) Habitat dynamics of beaver Castor canadensis at two spatial scales. Wildl Biol 14:302-308

Järvinen M, Rask M, Ruuhijärvi J, Arvola L (2002) Temporal coherence in water temperature and chemistry under the ice of boreal lakes (Finland). Water Res 36:3949-3956

Johansson P (1997) Lavfloran på bark och ved i naturreservatet Uppstaig —en gammal barrskog på Gotland. Svensk Bot Tidskr 91:65-75

Jones CG, Lawton JH, Shachak M (1994) Organisms as ecosystem engineers. Oikos 69:373-386 
Koleff P, Gaston KJ, Lennon JJ (2003) Measuring beta diversity for presence-absence data. J Anim Ecol 72:367-382

Komonen A, Niemi ME, Junninen K (2008) Lakeside riparian forests support diversity of wood fungi in managed boreal forest. Can J For Res 38:2650-2659

Kuuluvainen T (1994) Gap disturbance, ground micro-topography, and the regeneration dynamics of boreal coniferous forests in Finland, a review. Ann Zool Fenn 31:35-51

Kuusinen M, Siitonen J (1998) Epiphytic lichen diversity in oldgrowth and managed Picea abies stands in southern Finland. J Veg Sci 9:283-292

Laaka S (1995) Epixylic lichens on conifer logs in four natural forests in Finland. Graphis Scr 7:25-31

Lahti S, Helminen M (1974) The beaver Castor fiber (L.) and C. canadensis (Kuhl) in Finland. Acta Theriol 19:177-189

Lassauce A, Paillet Y, Jactel H, Bougeta C (2011) Deadwood as a surrogate for forest biodiversity: metaanalysis of correlations between deadwood volume and species richness of saproxylic organisms. Ecol Ind 11:1027-1039

Linnamies O (1956) Majavien esiintymisestä ja niiden aiheuttamista vahingoista maassamme. Suom Riista 10:63-86 [In Finnish]

Liu Q-H, Hytteborn H (1991) Gap structure, disturbance and regeneration in a primeval Picea abies forest. J Veg Sci 2:391-402

Lõhmus A, Lõhmus P (2011) Old-forest species: the importance of specific substrata vs. stand continuity in the case of calicioid fungi. Silva Fenn 45(5):1115-1139

McDowell DM, Naiman RJ (1986) Structure and function of a benthic invertebrate stream community as influenced by beaver (Castor canadensis). Oecologia 68:481-489

Nummi P (1989) Simulated effects of the beaver on vegetation, invertebrates and ducks. Ann Zool Fenn 26:43-52

Nummi P, Hahtola A (2008) The beaver as an ecosystem engineer facilitates teal breeding. Ecography 31:519-524

Nummi P, Holopainen S (2014) Whole-community facilitation by beaver: ecosystem engineer increases waterbird diversity. Aquat Conserv 24:623-633

Nummi P, Kuuluvainen T (2013) Forest disturbance by an ecosystem engineer: beaver in boreal forest landscapes. Boreal Environ Res 18:13-24

Nummi P, Kattainen S, Ulander P, Hahtola A (2011) Bats benefit from beavers: a facilitative link between aquatic and terrestrial food webs. Biodivers Conserv 20:851-859

Östlund L, Zackrisson O, Axelsson AL (1997) The history and transformation of a Scandinavian boreal forest landscape since the 19th century. Can J For Res 27:1198-1206

Parker H, Nummi P, Hartman G, Rosell F (2012) Invasive North American beaver Castor canadensis in Eurasia: a review of potential consequences and a strategy for eradication. Wild Biol 18(4):354-365

Prestø T. (1994) Bryophytes on decaying wood in the Urvatnet area, central Norway. Cand. scient. thesis, University of Trondheim

R Development Core Team (2013) R: a language and environment for statistical computing. The R Foundation for Statistical Computing, Vienna. ISBN: 3-900051-07-0. http://www.R-project.org/

Rikkinen J (1995) What's behind the pretty colours? A study on the photobiology of lichens. Bryobrothera 4:1-239

Rikkinen J (2003a) New resinicolous ascomycetes from beaver scars in western North America. Ann Bot Fenn 40:443-450

Rikkinen J (2003b) Calicioid lichens and fungi in the forests and woodlands of western Oregon. Acta Bot Fenn 175:1-41

Rosell F, Bozsér O, Collen P, Parker H (2005) Ecological impact of beavers Castor fiber and Castor canadensis and their ability to modify ecosystems. Mamm Rev 35:248-276

Rudolphi J, Caruso A, von Cräutlein M, Laaka-Lindberg S, Ryömä R, Berglund H (2011) Relative importance of thinned and clear-cut stands for bryophyte diversity on stumps. For Ecol Manag 261:1911-1918

Sabo JL, Soykan CU (2014) Riparian zones increase regional richness by supporting different, not more, species: reply. Ecology 87(8):2128-2131

Samuelsson J, Gustafsson L, Ingelög T (1994) Dying and dead trees-a review of their importance for biodiversity. Swedish University of Agricultural Science, Uppsala

Schlosser IJ, Kallemeyn LW (2000) Spatial variation in fish assemblages across a beaver influenced successional landscape. Ecology 81:1371-1782

Selva SB (1994) Lichen diversity and stand continuity in the northern hardwoods and spruce-fir forests of northern New England and western New Brunswick. Bryologist 94:424-428 
Selva SB (2003) Using calicioid lichens and fungi to assess ecological continuity in the Acadian Forest ecoregion of the Canadian Maritimes. For Chron 79:550-558

Selva SB (2013) The calicioid lichens and fungi of the Acadian Forest ecoregion of northeastern North America, I. New species and range extensions. Bryologist 116:248-256

Selva SB (2014) The calicioid lichens and fungi of the Acadian Forest ecoregion of northeastern North America, II. The rest of the story. Bryologist 117:336-367

Siitonen J (2001) Forest management, coarse woody debris and saproxylic organisms: fennoscandian boreal forests as an example. Ecol Bull 49:11-41

Sippola AL, Siitonen J, Kallio R (1998) Amount and quality of coarse woody debris in natural and managed coniferous forests near the timberline in Finnish Lapland. Scand J For Res 13:204-214

Spribille T, Björk CR (2008) New records and range extensions in the North American lignicolous lichen flora. Mycotaxon 105:455-468

Stokland JN, Siitonen J, Jonsson BG (2012) Biodiversity in dead wood. Cambridge University Press, Cambridge

Thompson S, Vehkaoja M, Nummi P (2016) Beaver-created deadwood dynamics in the boreal forest. For Ecol Manag 360:1-8

Tibell L (1984) A reappraisal of the taxonomy of Caliciales. Nova Hedwig Beih 79:597-714

Tibell L (1992) Crustose lichens as indicators of forest continuity in boreal coniferous forests. Nord J Bot 12:427-450

Tibell L (1999) Calicioid lichens and fungi. Nord Lichen Flora 1:20-94

Tuovila H (2013) Sticky business-diversity and evolution of Mycocaliciales (Ascomycota) on plant exudates. Ph.D. Dissertation, University of Helsinki

Turner MG, Gardner RH, O'Neill RV (2003) Landscape ecology in theory and practice. Springer, New York

Vehkaoja M, Nummi P (2015) Beaver facilitation in the conservation of boreal anuran communities. Herpetozoa 28(1/2):75-87

Vehkaoja M, Nummi P, Rask M, Tulonen T, Arvola L (2015) Spatiotemporal dynamics of boreal landscapes with ecosystem engineers: beavers influence the biogeochemistry of small lakes. Biogeochemistry $124: 405-415$

Wright JP, Jones CG (2004) Predicting effects of ecosystem engineers on patch-scale species richness from primary productivity. Ecology 85:2071-2081

Wright JP, Jones CG (2006) The concept of organisms as ecosystem engineers ten years on: progress, limitations, and challenges. Bioscience 56:203-209

Wright JP, Jones CG, Flecker AS (2002) An ecosystem engineer, the beaver, increases species richness at the landscape scale. Oecologia 132:96-101

Zuur AF, Ieno EN, Walker NJ, Saveliev AA, Smith GM (2009) Mixed effects models and extension in ecology with R. Springer, New York 